\title{
PENURUNAN KECEMASAN IBU NIFAS MENGGUNAKAN TOTOK WAJAH DI FASILITAS PELAYANAN PERSALINAN
}

\author{
Sumantri, Dewi Susilowati, Dian Kurnia Wati \\ Kementerian Kesehatan Politeknik Kesehatan Surakarta Jurusan Kebidanan
}

\begin{abstract}
Full-Blooded Face, Anxiety, Mother Postpartum. Post partum (puerperal) is the future return of the reproductive organs such as the state before becoming pregnant within six weeks after delivery. One of the psychological disorders suffered postpartum mothers is anxiety. Blooded face is a complementary therapy to reduce stress and anxiety. The aim of research to determine the effect on reducing anxiety blooded face puerperal women in childbirth care facility in Wonogiri districts. This study uses a pre-experimental design with one group pretest posttest design. Population in this research is the post partum mothers who gave birth and postpartum controls in BPM Siti Syamsiyah Wonogiri and RB. Nur Annisa Wonogiri in March-May 2014. The sampling technique using purposive sampling. Data were analyzed using the Wilcoxon test. Assessment of anxiety 30 minutes before full-blooded face the majority of mild anxiety, as many as 23 respondents (58.97\%). Assessment of anxiety 24 hours after the majority of full-blooded face no anxiety as much as 33 respondents $(84.61 \%)$. Blooded face significantly influence the decrease in anxiety scores. $\rho=0.00(\rho<0.05) ; x=16.20$ to 8.46. The magnitude of the effect of \pm 7.74. There is a full-blooded face effect on reducing anxiety postpartum mothers. Recommendations for delivery care facilities to be able to apply blooded face for postpartum mothers.
\end{abstract}

Keywords: Full-Blooded Face, Anxiety, Mother Postpartum.

Abstrak: Totok Wajah, Kecemasan, Ibu Nifas. Masa nifas (puerperium) adalah
masa kembalinya organ reproduksi seperti keadaan sebelum hamil dalam waktu
enam minggu setelah melahirkan. Salah satu gangguan psikologis yang dialami
ibu nifas adalah kecemasan. Totok wajah merupakan salah satu terapi
komplementer untuk mengurangi stress dan kecemasan. Tujuan penelitian untuk
mengetahui pengaruh totok wajah terhadap penurunan kecemasan ibu nifas di
fasilitas pelayanan persalinan di wilayah kecamatan Wonogiri. Penelitian ini
menggunakan rancangan pra-eksperimen dengan one group pretest posttest
design. Populasi dalam penelitian ini adalah ibu nifas yang melahirkan dan
kontrol nifas di BPM Siti Syamsiyah Wonogiri dan RB. Nur Annisa Wonogiri
pada bulan Maret- Mei 2014. Teknik pengambilan sampel menggunakan
purpossive sampling. Analisa data menggunakan uji Wilcoxon. Penilaian
kecemasan 30 menit sebelum totok wajah mayoritas kecemasan ringan, sebanyak
23 responden (58,97\%). Penilaian kecemasan 24 jam setelah totok wajah
mayoritas tidak ada kecemasan sebanyak 33 responden $(84,61 \%)$. Totok wajah
berpengaruh secara signifikan terhadap penurunan skor kecemasan. $\rho=0,00$
( $<<0,05)$; $x=16,20-8,46$. Besarnya pengaruh sebesar $\pm 7,74$. Ada pengaruh totok 
wajah terhadap penurunan kecemasan ibu nifas. Rekomendasi bagi fasilitas pelayanan persalinan untuk bisa menerapkan totok wajah bagi ibu nifas.

Kata Kunci: Totok Wajah, Kecemasan, Ibu Nifas.

\section{PENDAHULUAN}

Masa nifas (puerperium) adalah masa kembalinya organ reproduksi seperti keadaan sebelum hamil dalam waktu enam minggu setelah melahirkan (Nirwana, 2011:59). Dalam masa nifas, ibu nifas akan mengalami adaptasi fisiologis, psikologis dan adaptasi sosial. Namun, tidak semua ibu nifas bisa melewati adaptasi masa nifas dengan lancar. Ibu nifas bisa saja mengalami gangguan psikologis masa nifas (Simkin, 2008:333).

Salah satu gangguan psikologis yang dialami ibu nifas adalah kecemasan. Simkin (2008) menyebutkan bahwa $20 \%$ dari wanita pasca bersalin mengalami ganguan perasaan pasca melahirkan dengan gejala kecemasan dan panik (p.333). Pieter (2013) menyebutkan bahwa diperkirakan terdapat 10 dari 40 orang ibu pasca melahirkan mengalami depresi post partum. Sedangkan kasus baby blues bisa terjadi pada $50-80 \%$ ibu yang baru melahirkan (p.275).

Ada beberapa upaya yang
dilakukan kecemasan. Menurut pengalaman penulis, di daerah Wonogiri, ibu nifas biasa mengkonsumsi jamu kepyokan untuk melancarkan ASI dan jamu kunyit asam untuk mengurangi nyeri perut. Selain itu ibu nifas biasa menggunakan pilis untuk mengurangi sakit kepala. Tetapi ada juga sebagian orang yang segera menuju ke tenaga kesehatan, khususnya bidan untuk sekedar berkonsultasi.

Selain konvensional, ada pula terapi komplementer untuk mengatasi kecemasan yang ditujukan untuk pelepasan hormon endorfin, yaitu hormon kebahagiaan. Beberapa terapi komplementer yang diterapkan untuk merangsang pelepasan endorfin antara lain; mendengarkan musik, aktivitas seksual, konsumsi coklat hitam, meditasi, terapi relaksasi, studi akupuntur dan terapi pijat (Vad, 2010 dalam http://www.innerself.com, 10 januari 2014).

Totok wajah juga merupakan terapi salah satu komplementer yang berguna untuk mengurangi stress dan kecemasan (Kwan, 2010:13). Penekanan pada titik- titik akupuntur pada wajah bertujuan untuk mengirim sinyal yang menyeimbangkan sistem syaraf atau melepaskan bahan kimia seperti endorfin yang mengurangi rasa sakit dan stress (Trionggo, 2013:5).

Dalam bidang pelayanan kebidanan juga mulai bermunculan pelayanan kebidanan berbasis terapi komplementer. Salah satu bidan praktek mandiri di Blora melengkapi pelayanan kebidanannya dengan post natal nature treatment, dengan perawatan meliputi totok wajah, pijat ASI, pemijatan dan pemasangan bengkung. Di daerah Wonogiri, sebuah rumah bersalin juga memberikan terapi totok wajah dan pemijatan sebagai pelayanan tambahan bagi pasien.

\section{METODE PENELITIAN}

Penelitian ini menggunakan rancangan pra-eksperimen (pre experimental design). Desain yang digunakan dalam penelitian ini adalah 
one group pretest posttest design. Penelitian dilakukan pada bulan 17 Maret- 15 Mei 2014. Penelitian dilakukan di BPM Siti Syamsiyah dan RB. Nur Annisa Wonogiri. Sampelnya adalah Ibu nifas pada hari ketigakesepuluh sebanyak 34. Menggunakan kuesioner HARS (Hamilton Anxiety Rating Scale) terdiri dari 14 kelompok gejala kecemasan.

\section{HASIL PENELITIAN}

\section{Tabel 1}

Karakteristik responden

\begin{tabular}{clcc}
\multicolumn{3}{c}{ berdasarkan usia dan paritas } \\
\hline \multirow{2}{*}{ No } & $\begin{array}{l}\text { Karakteristik } \\
\text { responden }\end{array}$ & $\mathrm{F}$ & $\%$ \\
\hline $1 \quad$ & Usia & 35 & $\begin{array}{c}89,7 \\
4\end{array}$ \\
\hline \multirow{2}{*}{$20-30$ tahun } & 4 & $\begin{array}{c}10,2 \\
6\end{array}$
\end{tabular}

\begin{tabular}{clcc}
\hline & Sectio Cesaria & 25 & 64,10 \\
\cline { 2 - 4 } & Vacuum Ekstraksi & 1 & 2,56 \\
\hline 3 & Pelaksanaan IMD & & \\
\cline { 2 - 4 } & Dilaksanakan & 12 & 30,77 \\
\cline { 2 - 4 } & Tidak dilaksakan & 27 & 69,23 \\
\hline $\mathrm{n}=39$ & & &
\end{tabular}

Gambaran kecemasan ibu nifas sebelum dan sesudah dilakukan totok wajah dapat dilihat pada gambar 4.1 dibawah ini.

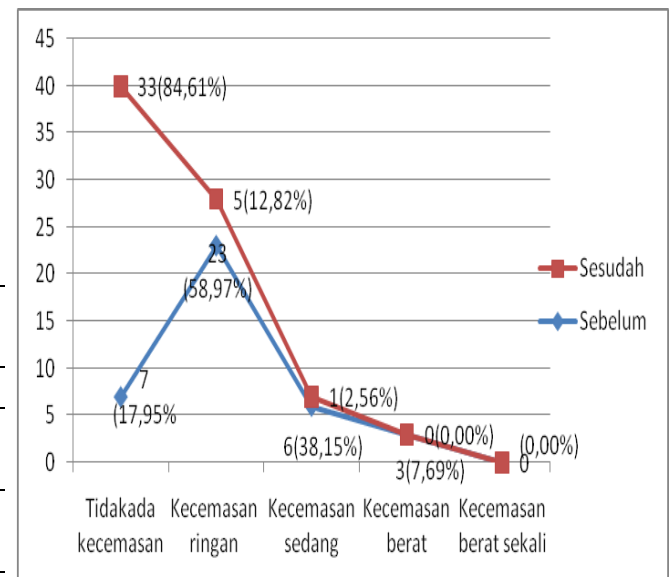

\begin{tabular}{clcc}
\hline 2 & Paritas & & \\
\hline & Primipara & 18 & 46,1 \\
& & 5 \\
\hline & Multipara & 21 & 53,8 \\
& & & 5 \\
\hline & Grande multi para & 0 & 0,00 \\
\hline $\mathrm{n}=39$ & & &
\end{tabular}

Tabel 2

Karakteristik Struktur Keluarga Responden

\begin{tabular}{lll}
\hline Struktur keluarga & $\mathrm{f}$ & $\%$ \\
\hline Keluarga inti & 10 & 25,64 \\
$\mathrm{n}=39$ & 29 & 74,36 \\
\hline Keluarga besar & &
\end{tabular}

Tabel 3

Karakteristik Responden Berdasarkan Perencanaan

Kehamilan, Jenis Persalinan dan Pelaksanaan IMD

\begin{tabular}{clcc}
\hline No & $\begin{array}{l}\text { Karakteristik } \\
\text { Responden }\end{array}$ & f & $\%$ \\
\hline 1 & $\begin{array}{l}\text { Perencanaan } \\
\text { kehamilan }\end{array}$ & & \\
\cline { 2 - 4 } & Direncanakan & 27 & 69,23 \\
\cline { 2 - 4 } & $\begin{array}{l}\text { Tidak } \\
\text { direncanakan }\end{array}$ & 12 & 30,76 \\
\hline 2 & Jenis persalinan & & \\
\cline { 2 - 4 } & Persalinan Spontan & 13 & 33,33 \\
\hline
\end{tabular}

Gambar 1. Penilaian kecemasan ibu nifas sebelum dan sesudah totok wajah

Grafik di atas dapat diketahui bahwa 30 menit sebelum totok wajah responden yang tidak ada gejala kecemasan sebanyak 7 responden $(17,95 \%)$. Sedangkan sebagian besar kecemasan adalah kecemasan ringan sebanyak 23 responden (58, 97\%), kecemasan sedang sebanyak 6 responden $(15,38 \%)$ dan kecemasan berat sebanyak 3 responden $(7,69 \%)$.

Setelah 24 jam dilakukan totok wajah, terjadi penurunan tingkat kecemasan, antara lain ibu nifas didominasi oleh tidak ada gejala kecemasan sebanyak 33 responden $(84,61 \%)$, kecemasan ringan 5 orang $(12,82 \%)$ dan kecemasan sedang hanya 1 responden $(2,56 \%)$.

Tabel 4

Pengaruh Totok Wajah Terhadap Penurunan Kecemasan Ibu Nifas 


\begin{tabular}{llll}
\hline $\begin{array}{l}\text { Totok } \\
\text { Wajah }\end{array}$ & $\bar{x}$ & Z score & $\rho$ \\
\hline $\begin{array}{l}\text { Sebelum- } \\
\text { sesudah }\end{array}$ & $16,20-$ & $-5,135$ & 0,001 \\
\hline Signifikan $=\rho<0,05$ & & \\
\hline
\end{tabular}

\section{PEMBAHASAN}

Dari hasil penilaian kecemasan sebelum dan sesudah totok wajah diketahui bahwa totok wajah efektif untuk responden dengan kecemasan ringan. Dapat diketahui bahwa sebelum totok wajah didominasi oleh kecemasan ringan, setelah totok wajah didominasi oleh tidak ada kecemasan. Dengan demikian dapat disimpulkan ada perubahan hasil penilaian kecemasan yaitu penurunan penilaian kecemasan.

Hasil penelitian ini ditegaskan oleh Kwan (2010). Dalam teorinya dijelaskan bahwa penurunan kecemasan yang dialami responden setelah totok wajah terjadi karena pijatan pada meridian (pembuluh darah sekunder) pada wajah bisa melancarkan sirkulasi darah (Kwan, 2010:8).

Gejala kecemasan yang dialami ibu nifas meliputi perasaan cemas, ketegangan, ketakutan, gangguan tidur, gangguan kecerdasan, perasaan murung, gejala somatik (otot), gejala somatik (sensorik), gejala kardiovaskuler, gejala pernafasan, gejala pencernaan, gejala urogenital, gejala autonom dan penilaian dari sikap wawancara (Hawari, 2006:81).

Respon dari responden setelah dilakukan totok wajah beragam. Dari 39 responden, 2 responden mengaku merasa mengantuk saat totok wajah sehingga responden bisa tertidur sejenak. Hal itu membuat responden senang karena beberapa hari yang lalu responden sering mengalami susah tidur. 3 orang responden juga mengaku merasa lebih segar setelah totok wajah. 2 orang lainnya juga mengatakan kepala menjadi terasa ringan sehingga tidak merasakan sakit kepala lagi. Secara keseluruhan responden berespon positif dan nyaman setelah totok wajah.

Penurunan keluhan kecemasan ibu nifas dijelaskan menurut penjelasan ilmiah, bahwa tekanan yang dilakukan dalam totok wajah berguna untuk mengirim sinyal yang menyeimbangkan sistem saraf atau melepaskan bahan kimia seperti endorfin yang mengurangi rasa sakit dan stress, membawa relaksasi dan mendukung proses penyembuhan di semua sistem lain. (Trionggo, 2013:8).

Karakteristik responden juga merupakan faktor pendukung keberhasilan totok wajah dalam upaya mengurangi kecemasan ibu nifas. Mayoritas responden yang berusia muda (20-35 tahun) lebih terbuka untuk menerima terapi totok wajah, karena lebih paham tentang manfaat totok wajah terhadap efek kenyamanan dan kecantikan. Begitu juga dengan responden multipara (mempunyai 2 anak atau lebih) cenderung lebih tertarik dengan terapi totok wajah yang diberikan, karena ibu tahu benar keadaan yang dialaminya dan totok wajah dianggap dapat membantu memulihkan kelelahan setelah melahirkan.

Karakteristik struktur keluarga menggambarkan dukungan keluarga terhadap kondisi responden. mayoritas responden tinggal dengan keluarga besar, yaitu sebanyak 29 responden $(74,36 \%)$ sangat mendukung efektifitas totok wajah terhadap penuruna kecemasan ibu nifas. Simkin (2008,333) menjelaskan bahwa kecemasan pada masa nifas bisa terjadi 
karena kurangnya dukungan dari keluarga.

Dalam melakukan pengumpulan data, keluarga yang mendampingi responden saat perawatan nifas menyambut baik terapi totok wajah yang diberikan. Selain suami, orang tua atau pun keluarga lain justru mendukung terapi totok wajah bagi ibu nifas. Selain karena memanfaatkan penawaran yang ada, keluarga juga mendukung supaya ibu nifas bisa merasa lebih rileks. Perencanaan kehamilan juga merupakan modal awal bagi kesiapan ibu menghadapi masa nifas sebagai masa transisi menjadi seorang ibu. Dua puluh tujuh responden $(69,23 \%)$ dengan kehamilan direncanakan lebih siap menghadapi masa nifas dan paham akan keadaan yang dialami pada masa nifas dan juga mudah menerima masukan, khususnya penawaran untuk dilakukan totok wajah. Terapi totok wajah menjadi lancar dan efektif karena responden lebih kooperatif menerima perawatan totok wajah.

Dari hasil penelitian diketahui bahwa banyak faktor yang berperan dalam menurunkan kecemasan ibu nifas. Karakteristik responden yang meliputi umur, paritas dan perencanaan kehamilan menunjang keefektifan totok wajah. Begitu juga dengan dukungan keluarga, menjadikan responden mempunyai kesempatan untuk bisa menikmati perawatan totok wajah dengan nyaman. Hanya saja yang diteliti dalam penelitian ini hanyalah pengaruh totok wajah terhadap kecemasan ibu nifas.

\section{KESIMPULAN DAN SARAN}

Kecemasan responden 30 menit sebelum dilakukan totok wajah mayoritas adalah kecemasan ringan, yaitu sebanyak 23 responden $(58,97 \%)$. Responden dengan kecemasan sedang sebanyak 6 responden $(15,38 \%)$, kecemasan berat sebanyak 3 responden $(7,69 \%)$ dan yang tidak ada kecemasan sebanyak 7 responden $(17,95 \%)$.

Kecemasan responden 24 jam setelah totok wajah mayoritas adalah tidak ada kecemasan sebanyak 33 responden $(84,61 \%)$. Responden dengan kecemasan ringan 5 responden $(12,82 \%)$ dan kecemasan sedang 1 responden $(2,56 \%)$.

Terdapat pengaruh yang signifikan dari totok wajah terhadap penurunan kecemasan ibu nifas. Skor $\rho=0,00(\rho<0,05) ; x=16,20-8,46 ; s d=$ 6,80- 4,67; Zscore $=-5,135$. Adapun besarnya pengaruh totok wajah terhadap penurunan skor kecemasan pada ibu nifas sebesar $\pm 7,74$ dibandingkan dengan skor kecemasan sebelum dilakukan totok wajah. Maka kesimpulannya adalah Ho dalam penelitian ini ditolak. Saran untuk penelitian ini adalah :

a. Ibu nifas lebih banyak mengakses info tentang manfaat totok wajah sebagai salah satu terapi komplementer.

b. Ibu nifas dengan kategori kecemasan sedang, berat dan berat sekali, totok wajah tidak hanya dilakukan sekali, bisa berulang kali sesuai kebutuhan.

\section{DAFTAR RUJUKAN}

Hawari, D., 2013, Manajemen Stres Cemas dan Depresi, Fakultas Kedokteran Universitas Indonesia, Jakarta.

Haruyama, S., 2013, The Miracle of Endorphin, Qanita, Bandung.

Jhaquin, A., 2010, Psikologi Untuk Kebidanan, Nuha Medika, Yogyakarta. 
39 Jurnal Kebidanan Dan Kesehatan Tradisional, Volume 1, No 1, Maret 2016, hlm 1-99

Kwan, H.K., 2010, Totok Aura/ Wajah Meridian 312 Cantik, Gramedia Pustaka Utama, Jakarta.

Nirwana, A. B., 2011, Psikologi Ibu, Bayi dan Anak, Nuha Medika, Bantul.

Simkin, P., et all, 2008, Panduan Lengkap Kehamilan, Melahirkan dan Bayi, Penerbit Arcan, Jakarta.
Trionggo, I., dkk., 2013, Panduan Sehat Sembuhkan Penyakit dengan Pijat dan Herbal, Indotoleransi, Yogyakarta.

UNICEF, 2011, Pelatihan Konseling Menyusui, English: WHO.

Pieter, H. Z., dkk, 2013, Pengantar Psikologi Untuk Kebidanan, EGC, Jakarta. 